\title{
Monitoring of $\beta$-Blockers Ozone Degradation via Electrospray Ionization Mass Spectrometry
}

\author{
Cristina Quispe ${ }^{a, d}$ Fabiane M. Nachtigall, ${ }^{b}$ Maria Francesca R. Fonseca, ${ }^{b}$ Rosana M. \\ Alberici, ${ }^{b}$ Luis Astudillo, ${ }^{c}$ Jorge Villaseñor, ${ }^{a}$ Marcos N. Eberlin ${ }^{b}$ and Leonardo S. Santos ${ }^{*, d}$ \\ ${ }^{a}$ Laboratory of Physical Chemistry, Instituto de Química de Recursos Naturales, Talca University, \\ PO Box 747, Talca, Chile \\ ${ }^{b}$ ThoMSon Mass Spectrometry Laboratory, Institute of Chemistry, University of Campinas, \\ 13083-970 Campinas-SP, Brazil
}

${ }^{c}$ Laboratory of Organic Synthesis and ${ }^{d}$ Laboratory of Asymmetric Synthesis, Talca University, PO Box 747, Talca, Chile

\begin{abstract}
As estruturas dos produtos de degradação mediada por ozônio de diferentes compostos farmacêuticos foram estudadas. Uma completa degradação do nadolol foi observada nas condições empregadas após 100 min. Os produtos de degradação obtidos nas soluções aquosas foram caracterizados por espectrometria de massas com ionização por electrospray (ESI-MS e ESI-MS/MS). O mecanismo proposto para a degradação consiste inicialmente do ataque de ozônio ao grupo amino da anilina formando nitro compostos, seguida de uma série de processos oxidativos. Monitoramento por ESI-MS(/MS) mostrou que a degradação de atenolol (ATE) e acebutolol (ACE) por ozônio ocorrem via um mecanismo similar ao do nadolol.
\end{abstract}

The structures of intermediate products of ozone degradation of different pharmaceutical compounds have been studied. Under the conditions employed, complete ozone degradation of nadolol was achieved after $100 \mathrm{~min}$. The degradation products obtained in aqueous solution were characterized by electrospray ionization mass (and tandem mass) spectrometry (ESI-MS and ESI-MS/MS). The proposed mechanism for degradation, ozone attacks at the aniline amino group giving rise to nitro compounds and further degradation occurs via a series of oxidative processes. Continuous online monitoring by ESI-MS(/MS) with high accuracy mass measurements showed that ozone degradation of atenolol (ATE) and acebutolol (ACE) occurs via mechanisms similar to that of nadolol.

Keywords: ozonation, degradation, ESI-MS, pharmaceutical compounds, reaction mechanism

\section{Introduction}

Concerns about the prejudicial effects to life of accumulation of pharmaceuticals in the environment has greatly increased in recent years. ${ }^{1,2}$ But such accumulation is governed mainly by the environmental bio- and photo-transformation ${ }^{3}$ and the speed and nature of the natural degradation of these potentially harmful contaminants. ${ }^{4,5}$ The photolytic degradation of chemicals in the environment may occur via direct sunlight absorption or by reactions with strong oxidizing species such as hydroxyl radicals and singlet oxygen.

*e-mail: 1ssantos@utalca.cl
Pharmaceuticals enter the aquatic environment after its ingestion by humans and other animals and subsequent excretion, either in their intact forms or as metabolites. ${ }^{6}$ Wastewater treatment is applied worldwide but pharmaceuticals may not be efficiently removed, ${ }^{3,7}$ and these pharmaceutical residues and degradation products can be downloaded directly into aquatic environments. Several studies have stated that the long-term risk to humans from any single pharmaceutical at sub- $\mu \mathrm{g} \mathrm{L}^{-1}$ levels is negligible, but the toxicological implications of chronic exposure to trace contaminants is still unclear. ${ }^{8,9}$

Ozonation is an advanced oxidation process widely used in many wastewater treatment plants for the oxidation of organic contaminants and disinfection. Ozone, compared to other most 
common oxidizing reagents such as $\mathrm{H}_{2} \mathrm{O}_{2}$ or chlorine, is more efficient in pollutant degradation and less harmful to most living organisms. ${ }^{10}$ In water, ozone can oxidize contaminants via direct selective reactions ${ }^{11}$ such as ozone addition to double bonds or the initiation of chain radical reactions by the production of free hydroxy radicals (equations 1-4). Hydroxy radicals are generated from ozone decomposition, which is catalyzed by the presence of hydroxyl anions or by traces of other substances, such as transition metal cations.

$$
\begin{aligned}
& \mathrm{O}_{3}+\mathrm{H}_{2} \mathrm{O} \rightarrow 2 \mathrm{HO}^{\bullet}+\mathrm{O}_{2} \\
& \mathrm{O}_{3}+\mathrm{OH}^{-} \rightarrow \mathrm{O}_{2}^{\bullet-}+\mathrm{HO}_{2}^{\bullet} \\
& \mathrm{O}_{3}+\mathrm{HO}^{\bullet} \rightarrow \mathrm{O}_{2}+\mathrm{HO}_{2}^{\bullet} \\
& \mathrm{O}_{3}+\mathrm{HO}_{2}^{\bullet} \rightarrow 2 \mathrm{O}_{2}+\mathrm{HO}^{\bullet}
\end{aligned}
$$

The decomposition of ozone in aqueous solutions is known to proceed via the chain reactions shown in equations $1-4 .{ }^{12}$ Ozone therefore indirectly attacks organic compounds since such reactions are faster than direct $\mathrm{O}_{3}$ attack. In previous studies, ${ }^{13,14}$ we described the $\mathrm{O}_{3}$ interaction with pharmaceutical compound nadolol (antihypertensive). In this study, we report the characterization via electrospray ionization mass spectrometry (ESI-MS) ${ }^{15,16}$ of the oxidation intermediates and products of degradation of nadolol generated during $\mathrm{O}_{3}$ oxidation. Furthermore, the $\mathrm{O}_{3}$ degradation of two other $\beta$-blockers compounds atenolol and acebutolol was also studied.

ESI-MS (and its tandem version ESI-MS/MS) has been used extensively to monitor the composition and degradation of organic compounds in the environment. ${ }^{17,18}$ ESI-MS(/MS) with its unique characteristics has become a major technique to elucidate reaction mechanism especially in aqueous solutions via the detection and identification of reactants, products, and intermediates, ${ }^{19,20}$ even the shortlived ones that occur at very low concentrations. ${ }^{21,22}$

Gas chromatography-mass spectrometry (GC-MS) has often been the technique of choice for reaction screening and product elucidation. ${ }^{23}$ However, GC-MS is an offline technique that demands extraction and sometimes derivatization pre-steps, transient, most polar, or relatively unstable compounds may be missed. We have then performed ESI-MS(/MS) monitoring of the $\mathrm{O}_{3}$ advanced oxidation of nadolol, atenolol and acebutolol in water to search for all intermediates and products of this environmentally important process. These products are the ones most likely to be found in treated wastewaters. We also used high performance liquid chromatography (HPLC), ultraviolet spectroscopy (UV), and total organic carbon (TOC) analyses to collect additional data on substrate degradation rates and mineralization and to investigate the presence of residual organic compounds in the aqueous solutions. ${ }^{24}$

\section{Experimental}

\section{Chemicals}

Nadolol (NAD), atenolol (ATE) and acebutolol (ACE) were purchased from Sigma. All the solvents were of HPLC grade and purchased from Merck and used without purification. Doubly distilled water was used to prepare all the solutions in the experiments. Ozone was generated using a laboratory ozone generation (OZOCAV) ozonizer fed with air/oxygen.

\section{Degradation procedures}

The ozonation reactions were performed in a batch glass reactor thermostated at $25^{\circ} \mathrm{C}$. The reactor was charged with $100 \mathrm{~mL}$ of the drug aqueous solutions $\left(1.6 \times 10^{-4} \mathrm{~mol} \mathrm{~L}^{-1}\right)$ and fed with $1.2 \times 10^{-4} \mathrm{~mol} \mathrm{~L} \mathrm{~L}^{-1}$ of ozone at a constant flow of $46 \pm 1 \mathrm{~mL} \mathrm{~min}{ }^{-1}$. The ozone concentration was monitored measuring the absorbance at $254 \mathrm{~nm}$, using the molar extinction coefficient of ozone of $2900 \mathrm{~L} \mathrm{~mol}^{-1} \mathrm{~cm}^{-1}$. Aliquots $(1.0 \mathrm{~mL})$ were taken at several reaction times and promptly analyzed by ESI-MS(/MS) and HPLC. All samples were protected from light and refrigerated at $4{ }^{\circ} \mathrm{C}$ prior to analyses.

\section{Analytic methods}

Drugs concentrations were monitored using a Perkin Elmer Series 200 chromatograph HPLC system equipped with a UV-Vis detector. A Merck-Chromolith Performance RP-18 column $(4.6 \mathrm{~mm} \times 100 \mathrm{~mm})$ was used with $\mathrm{H}_{2} \mathrm{O}: \mathrm{MeOH}(70: 30, \mathrm{v} / \mathrm{v})$ mobile phase at a flow rate of $0.6 \mathrm{~mL} \mathrm{~min}^{-1}$. Water was previously acidified to $\mathrm{pH} 3 \mathrm{using}$ aqueous solution of $\mathrm{HCl}$. Organic acids were quantified with a transgenomic ORH-801 column $(6.5 \mathrm{~mm} \times 300 \mathrm{~mm})$ using $5.0 \times 10^{-3} \mathrm{~mol} \mathrm{~L}^{-1}$ sulphuric acid as mobile phase at

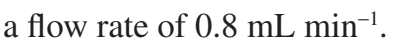

Ultraviolet (UV) absorbance measurements were performed using a HP 8453 (Agilent) spectrophotometer equipped with a quartz cell with a $1.0 \mathrm{~cm}$ path length. Absorbances were measured with baseline correction, scan rate of 200-600 nm, and integrate time of $0.5 \mathrm{~s}$ and intervals of $1 \mathrm{~nm}$.

Total organic carbon (TOC) experiments were carried out in a TOC 5000A (Shimadzu) instrument at $680^{\circ} \mathrm{C}$ using a platinum catalyst. 
ESI-MS(/MS) data were collected using a high resolution hybrid quadrupole $(\mathrm{Q})$ and orthogonal time-offlight (TOF) mass spectrometer (Q-Tof, Micromass UK) with constant nebulizer temperature of $50{ }^{\circ} \mathrm{C}$. The ESI source and the mass spectrometer were operated in the positive ion mode, and the cone and extractor potentials were set to 40 and $10 \mathrm{~V}$, respectively, with a scan range of $\mathrm{m} / \mathrm{z}$ 50-1000. Samples were infused into the ESI source at flow rates of ca $15 \mu \mathrm{L} \mathrm{min}^{-1}$ via a microsyringe pump. ESI-MS/MS experiments were carried out by selection of a specific ion in Q1 and by performing its collision-induced dissociation (CID) with argon in the collision chamber. The product ions MS analysis was accomplished with the high-resolution (ca. 5.000) and high accuracy (ca.10 ppm) orthogonal TOF analyzer.

\section{Results and Discussion}

\section{Degradation of nadolol}

Our investigation began with HPLC monitoring for the $\mathrm{O}_{3}$ degradation of nadolol (NAD) in an aqueous solution at a concentration of $1.6 \times 10^{-4} \mathrm{~mol} \mathrm{~L}^{-1}$ at $\mathrm{pH} 3$ or 9 , with $\mathrm{O}_{3}$ concentration at $1.2 \times 10^{-4} \mathrm{~mol} \mathrm{~L}^{-1}$ (Figure 1). Regardless the $\mathrm{pH}$ (acidic or basic), more than 90\% of NAD was found to be degraded after $60 \mathrm{~min}$ at similar rates. TOC analyses were then performed to evaluate the mineralization extent, which was found to be only $20 \%$ according to TOC removal. This result suggests that NAD was completely consumed after $60 \mathrm{~min}$ of $\mathrm{O}_{3}$ degradation, but desirable mineralization to $\mathrm{CO}_{2}, \mathrm{H}_{2} \mathrm{O}$ and $\mathrm{NH}_{3}$ was far for completion. UV monitoring of $\mathrm{O}_{3}$ degradation (Figure 2) also indicated complete NAD consumption, but little information is provided of the nature of the degradation products. The UV spectra of Figure 2i show three characteristic absorption bands of nadolol at 203, 217 and $277 \mathrm{~nm}$. After

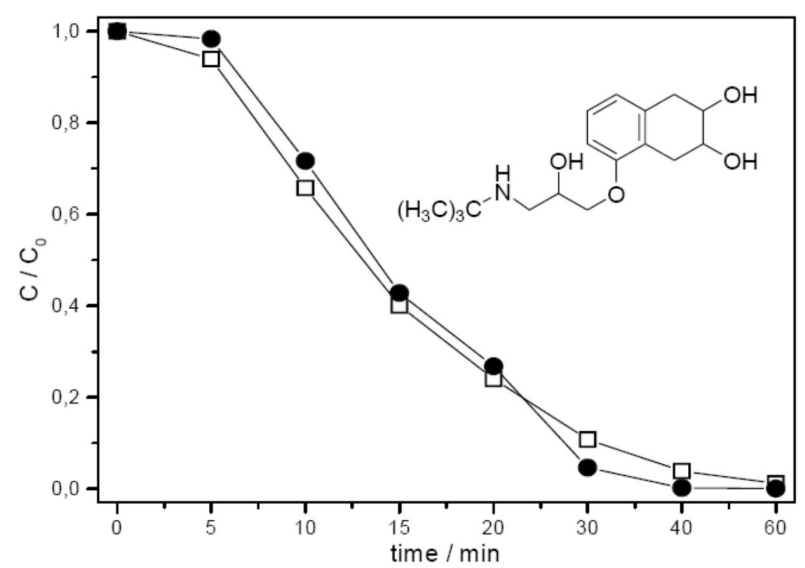

Figure 1. HPLC monitoring of the ozonation of nadolol at pH $3(\bullet)$ and pH 9 ( $\square)$.
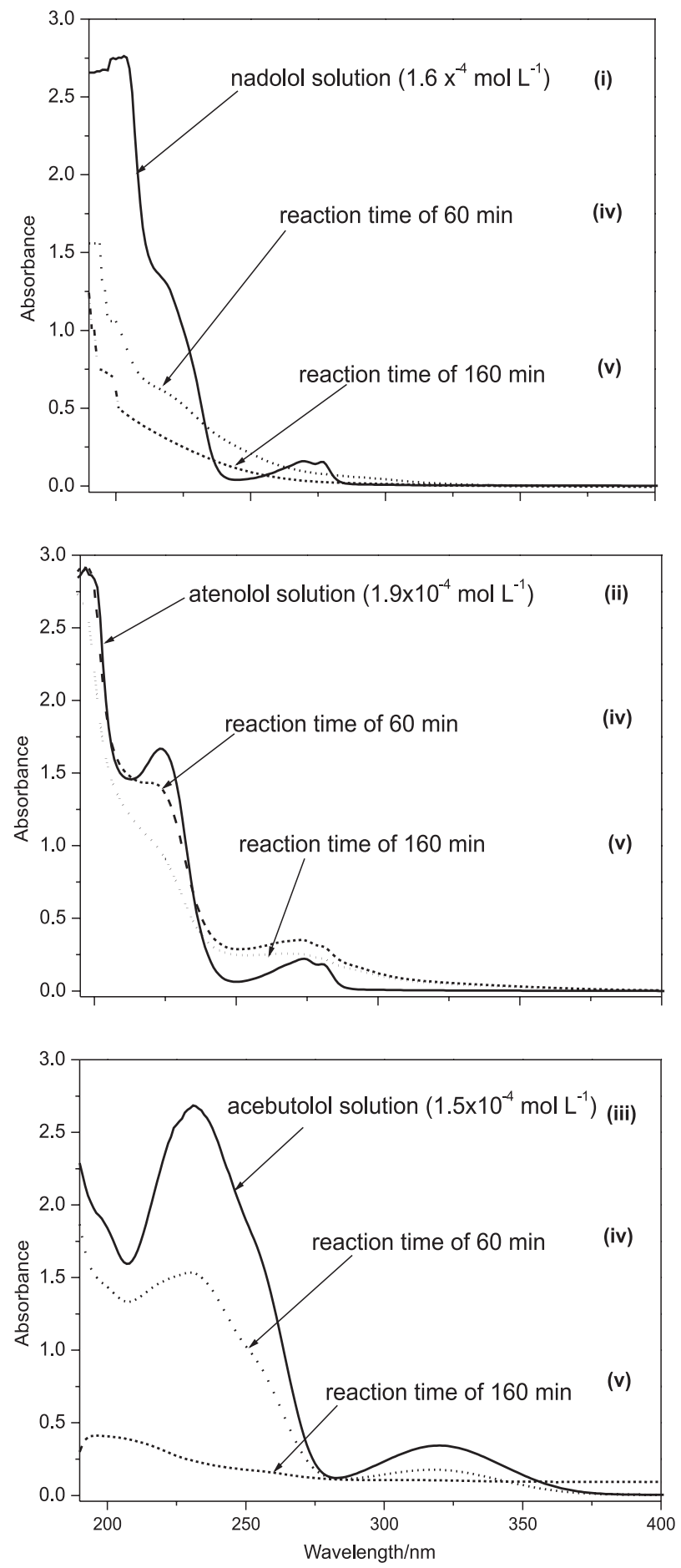

Figure 2. UV spectra of (i) an aqueous solution of nadolol at $1.6 \times 10^{-4} \mathrm{~mol} \mathrm{~L}^{-1}$, (ii) an aqueous solution of atenolol at $1.9 \times 10^{-4} \mathrm{~mol} \mathrm{~L}^{-1}$, (iii) an aqueous solution of acebutolol at $1.5 \times 10^{-4} \mathrm{~mol} \mathrm{~L}^{-1}$ and aliquots of the reaction mixture withdrawn after $60 \mathrm{~min}$ (iv) and $160 \mathrm{~min}$ (v) of ozone treatment respectively.

$\mathrm{O}_{3}$ treatment, the UV spectra show that intensities of these absorption bands were greatly reduced, suggesting nadolol was degraded, but not totally mineralized with persistent organic intermediates. 


\section{ESI-MS(/MS) monitoring}

Figure 3 displays representative $\mathrm{ESI}(+)$ mass spectra of nadolol aqueous solution ( $\mathrm{pH} 9)$ monitored after 60 , 100 and 160 min from ozone treatment. Similar spectra (not shown) were acquired when using solutions at $\mathrm{pH} 3$. The spectra at zero irradiation time (Figure 3a) detected, as expected, an intense ion of $\mathrm{m} / \mathrm{z} 310$ corresponding to protonated NAD. The ESI-MS/MS (Figure 4a) for collision induced dissociation of protonated NAD of $\mathrm{m} / \mathrm{z} 310$ shows a series of major and structurally diagnostic fragment ions arising from the loss of isobutene $(\mathrm{m} / \mathrm{z} 254), \mathrm{H}_{2} \mathrm{O}$ plus isobutene $(\mathrm{m} / \mathrm{z}, 236), 2 \times \mathrm{H}_{2} \mathrm{O}$ plus isobutene $(\mathrm{m} / \mathrm{z}, 218)$ and $\mathrm{NH}_{3}$ plus $2 \times \mathrm{H}_{2} \mathrm{O}$ and isobutene $(\mathrm{m} / \mathrm{z}, 201)$.

The degradation process was monitored by intervals of 20 min during 160 min of reaction. Illustrative spectra are displayed in Figure 3. The degradation of nadolol of $\mathrm{m} / \mathrm{z} 310$ was clearly perceived as well as the formation of organic intermediates. After 60 min of ozonation (Figure 3b), three additional and increasingly abundant ions of $\mathrm{m} / \mathrm{z}, 92,148$ and 236 were detected. The ion of $\mathrm{m} / \mathrm{z} 148$ (Figure 3d), which indicates the loss of a subunit of $161 \mathrm{Da}$ (from nadolol of $309 \mathrm{Da})$, was characterized as the protonated form of dihydroxylamine $\mathbf{2}$ (Figure 5). Further degradation of $\mathbf{2}$ afforded hydroxylamine $[3+\mathrm{H}]^{+}$by loss of isobutene as noted through the ion of $m / z$ 92, as depicted in Figure $3 \mathrm{~d}$.

The ion of $\mathrm{m} / \mathrm{z} 236$ (Figure 3d) was likely formed by aromatic ring opening, which produced a series of degradation products detected as the ions of $\mathrm{m} / \mathrm{z} 378$, 342 and 376. Furthermore, ESI-MS was able to gently and efficiently fish directly from the solution to the gas phase for MS analysis also an increasingly abundant ion of $m / z$ 236. This ion was characterized as aminotriol 9 (Figure 5). Figure 4c shows the ESI-MS/MS spectra of intermediate $[9+\mathrm{H}]^{+}$that dissociated by loss of isobutene $\left(\mathrm{C}_{4} \mathrm{H}_{8}\right)$ producing the fragment ion of $m / z 180$. That loss is indicative of tert-butyl group in the molecule, as observed in Figure 4. Another interesting fragmentation pathway was observed for $[9+\mathrm{H}]^{+}$by loss of $\mathrm{C}_{4} \mathrm{H}_{8} \mathrm{O}_{2}$, which structure could be realized as 2-hydroxytetrahydrofuran.

Two major mechanisms can be considered for $\mathrm{O}_{3}$ treatment. The first one assumes $\mathrm{O}_{3}$ addition to double bonds, whereas the second considers indirect reaction in water via hydroxyl radicals (equations 1-4). Formation of lower and higher masses intermediates was observed. Considering the lower mass compounds, Figure 5 presents a proposed route of degradation based on the ESI-MS(/MS) data, whereas Figure 6 presents proposed pathways
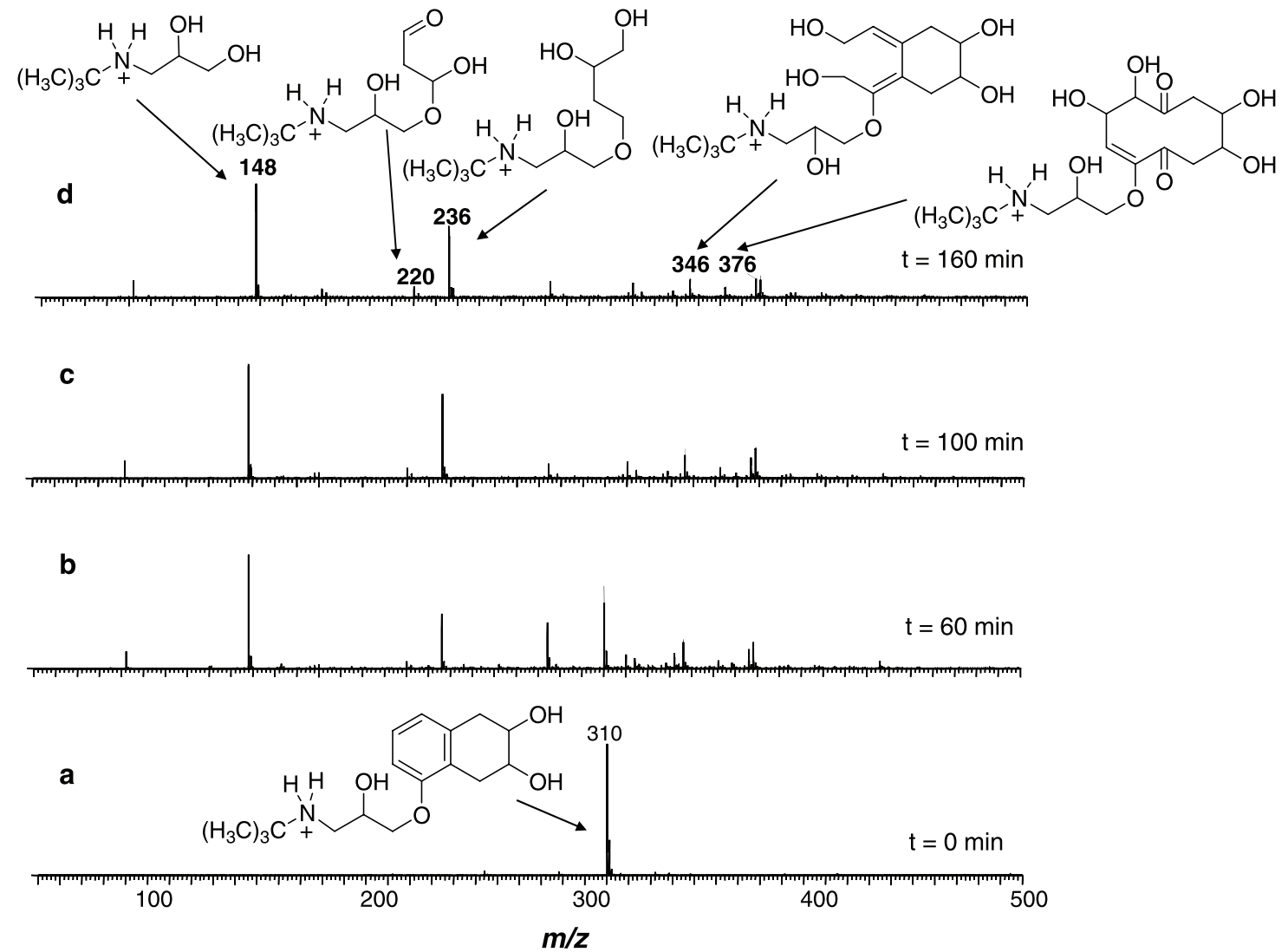

Figure 3. ESI(+) Mass spectra acquired for aliquots of the reaction mixture after $\mathrm{O}_{3}$ treatment of nadolol at pH 9 for (a) 0 min; (b) 60 min; (c) 100 min and (d) $160 \mathrm{~min}$. 
leading to the higher mass products. HPLC analyses with standards corroborated unequivocally the structure of several structures proposed for the intermediates detected and characterized by ESI-MS(/MS). Among them are oxalic acid, formic acid and glyoxylic acid, which are known as recalcitrant compounds very resistant to further degradations. ${ }^{13}$ The resistance for this class of compounds is due to the lack of $\mathrm{C}-\mathrm{H}$ bonds, and this may explaining why oxalic acid was less susceptible to $\mathrm{OH}^{\bullet}$ radicals attack which are produced mainly at high $\mathrm{pH}$ from $\mathrm{O}_{3}$. Thus, although the parent NAD was totally consumed by $\mathrm{O}_{3}$ treatment at different $\mathrm{pH}$ in a similar reaction rates, the intermediates observed in solution at $\mathrm{pH} 3$ or 9 were different.

\section{Degradation of atenolol}

The degradation of atenolol (ATE) by $\mathrm{O}_{3}$ was monitored at either $\mathrm{pH} 3$ or 9 . Figure 2 shows UV spectra of the degradation of atenolol $\left(1.9 \times 10^{-4} \mathrm{~mol} \mathrm{~L}^{-1}\right)$ by ozone at $\mathrm{pH}$ 3. Similar results (not shown) were obtained at $\mathrm{pH} 9$. Three characteristic absorption bands of atenolol at seen at 200, 223 and $274 \mathrm{~nm}$. TOC analyses indicated only $15 \%$
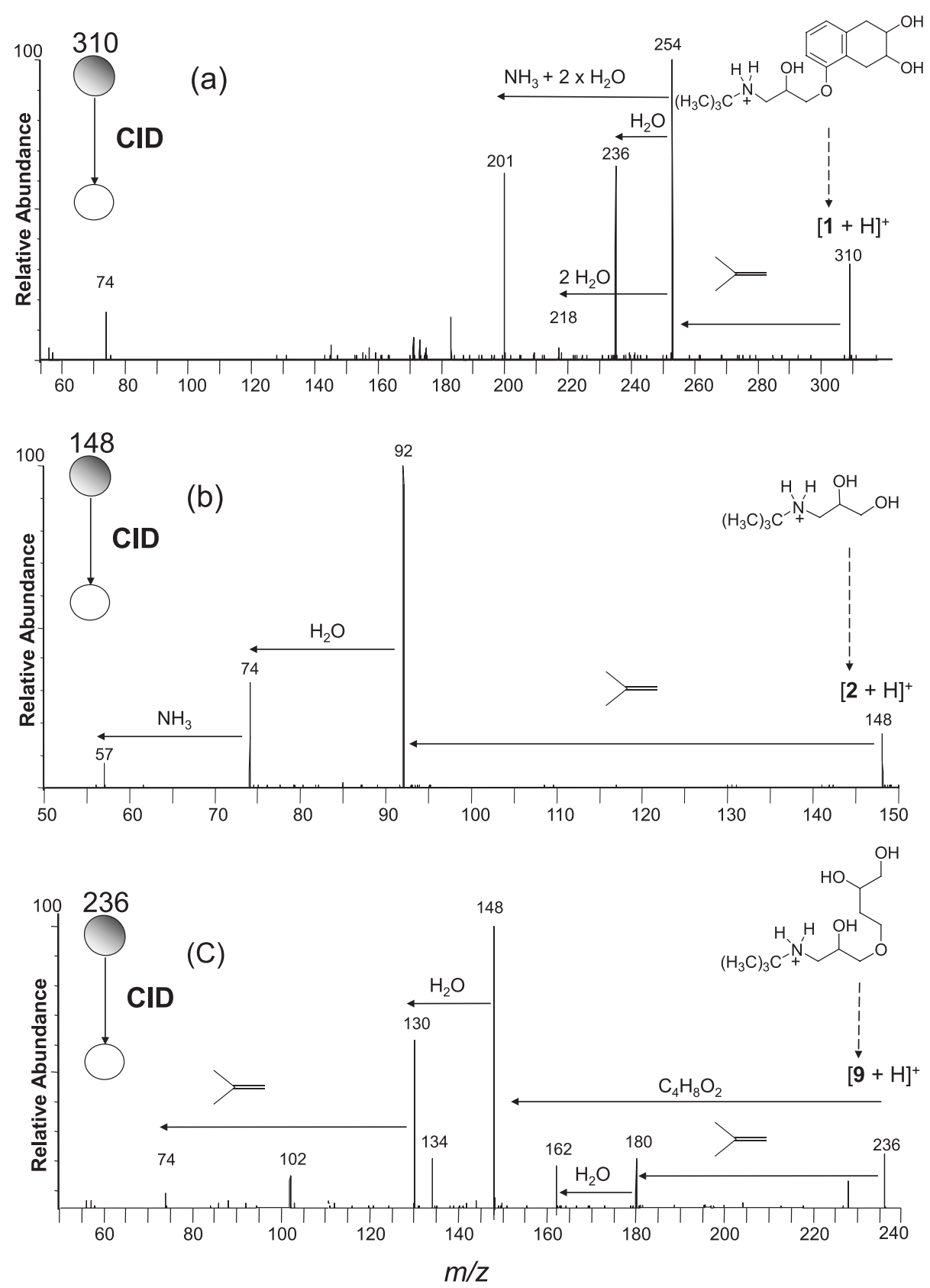

Figure 4. ESI-MS/MS of (a) protonated nadolol $[\mathbf{1}+\mathrm{H}]^{+}$of $\mathrm{m} / \mathrm{z} 310$; (b) the ion of $\mathrm{m} / \mathrm{z} 148$ attributed to $[2+\mathrm{H}]^{+}$; and (c) the ion of $\mathrm{m} / \mathrm{z} 236$ attributed to $[9+\mathrm{H}]^{+}$. 

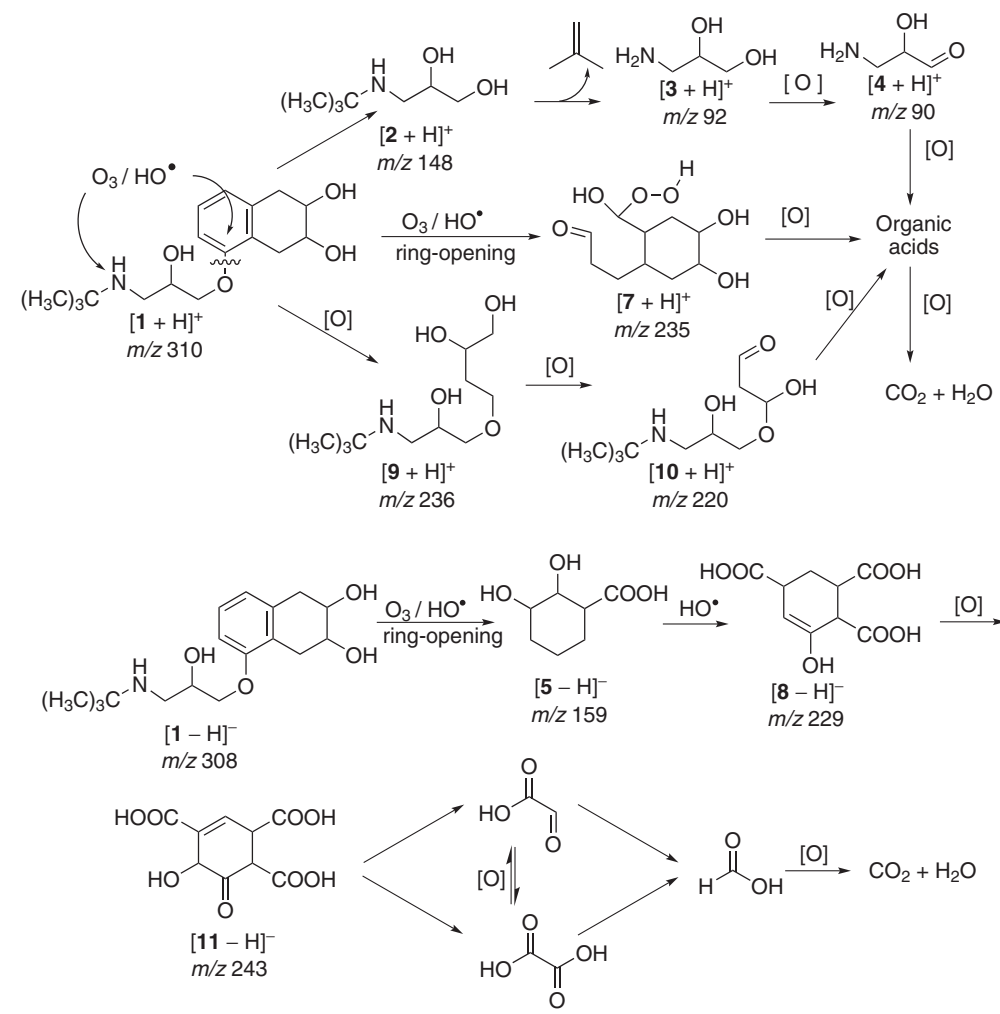

Figure 5. Mechanism proposed for nadolol (NAD) degradation by ozone based on ESI-MS(/MS) data (lower mass products).

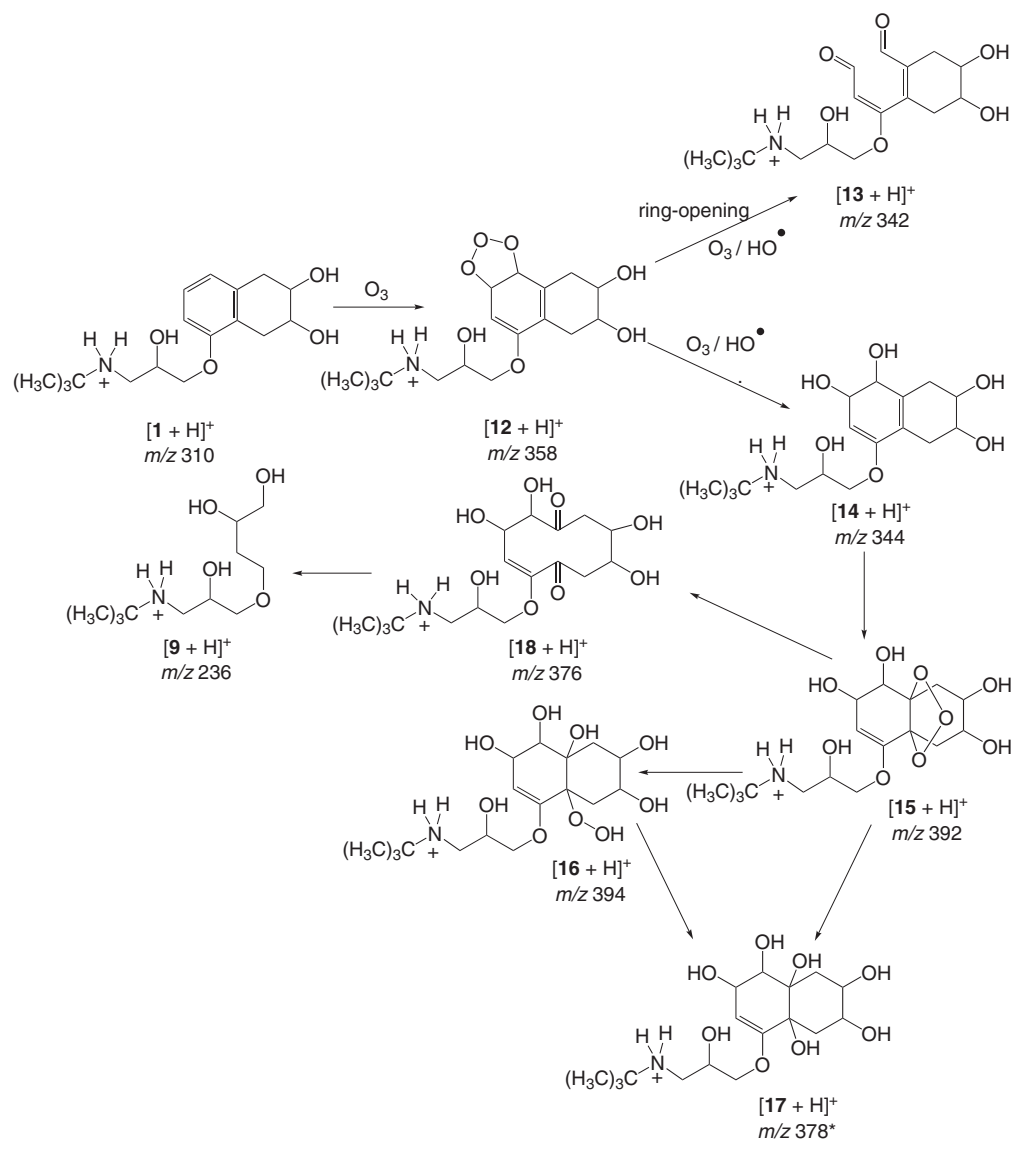

Figure 6. Mechanism proposed for nadolol (NAD) degradation by ozone based on ESI-MS(/MS) data (higher mass products). 
of mineralization. These results suggested, as for NAD, that the mineralization leading to $\mathrm{CO}_{2}, \mathrm{H}_{2} \mathrm{O}$ and $\mathrm{NH}_{3}$ was mostly incomplete.

Figure 7 displays representative ESI(+)-MS of atenolol aqueous solutions according with time at $\mathrm{pH}$ 3. Similar spectra (not shown) were acquired at pH 9. The ESI-MS at zero irradiation time (Figure 7a) shows, as expected, predominantly the ion of $\mathrm{m} / \mathrm{z} 267$ for protonated ATE. After $160 \mathrm{~min}$ of ozonation (Figure $7 \mathrm{~b})$, ATE $(\mathrm{m} / \mathrm{z}, 267)$ was totally consumed and three intense ions of $m / z$ 134, 206 and 222 were observed. It was reported that photocatalytic $\mathrm{TiO}_{2}$ degradation ${ }^{25}$ and biological advanced oxidation ${ }^{26}$ of atenolol afforded comparable degradation products as characterized by ESI-MS. Furthermore, the degradation species reported through $\mathrm{TiO}_{2}$ and biodegradation suggested a $\mathrm{HO}^{\bullet}$ radical Fenton-like pathway showing higher mass products than observed by us. However, based on the ESI-MS(/MS) data, a different mechanism for $\mathrm{O}_{3}$ treatment of atenolol is proposed as depicted in Figure 8.

\section{Degradation of acebutolol}

Figure 2 shows the UV spectra for the $\mathrm{O}_{3}$ treatment of acebutolol $\left(1.5 \times 10^{-4} \mathrm{~mol} \mathrm{~L}^{-1}\right)$. The two characteristic absorption bands of acebutolol are those at 231 and $320 \mathrm{~nm}$. As observed previously for nadolol and atenolol, complete consumption of the parent molecule is achieved but $15 \%$ of TOC removal was observed.

Figure 9 displays two representative ESI(+)-MS of acebutolol solutions for $\mathrm{O}_{3}$ treatment. The ESI-MS at zero irradiation time (Figure 9a) detects, as expected, the ion of $\mathrm{m} / \mathrm{z} 337$ corresponding to protonated acebutolol.

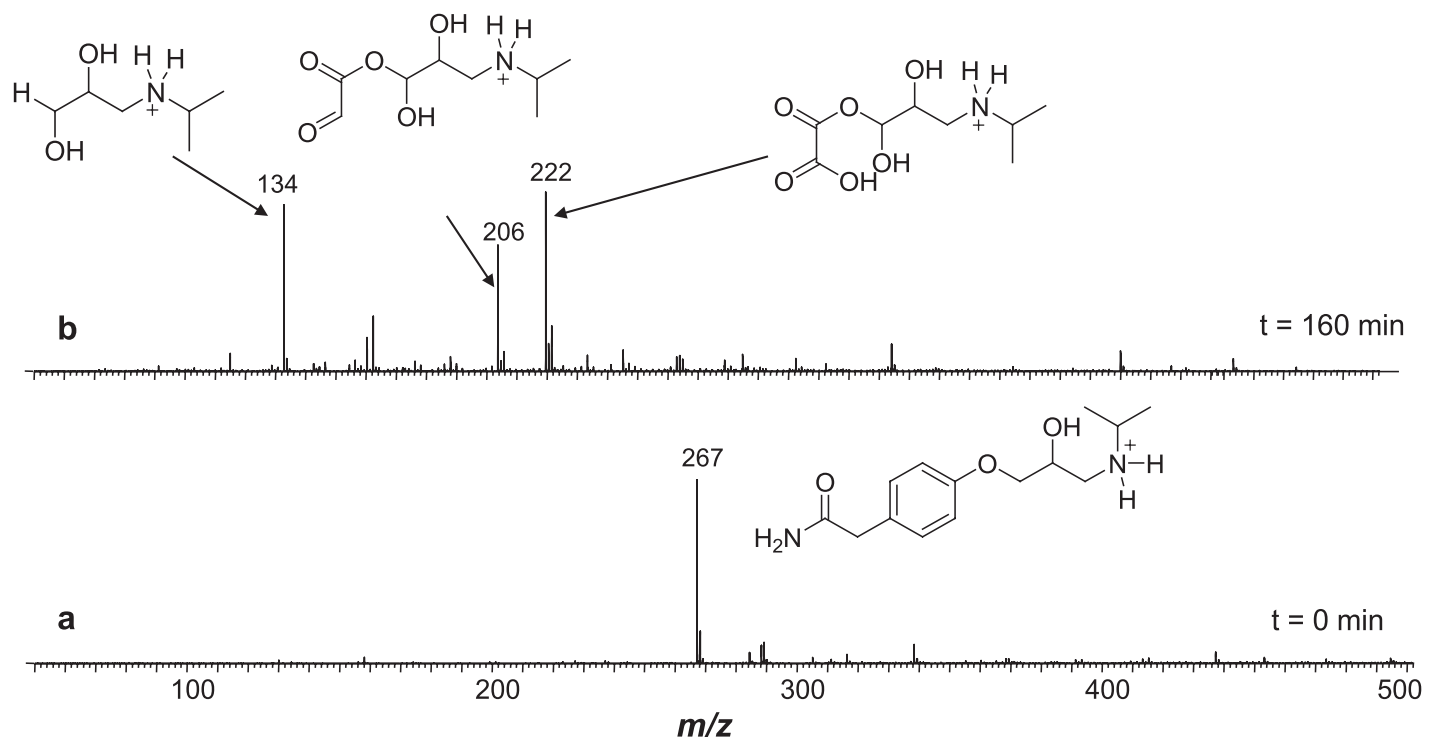

Figure 7. ESI(+) Mass spectra acquired for aliquots of the reaction mixture after degradation of atenolol with ozone system for (a) 0 min and (b) $160 \mathrm{~min}$.

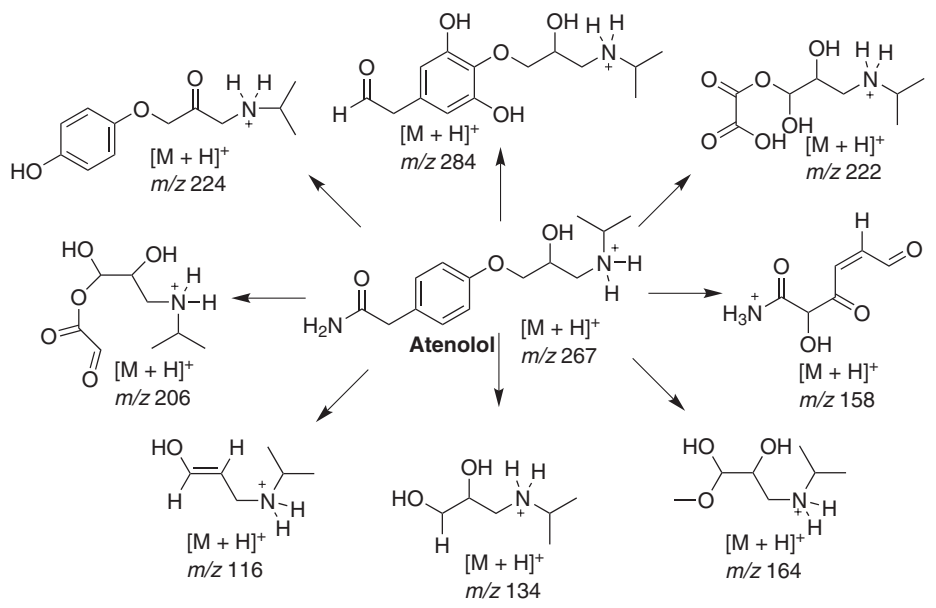

Figure 8. Mechanism proposed for atenolol degradation by ozone based on ESI-MS(/MS) data. 


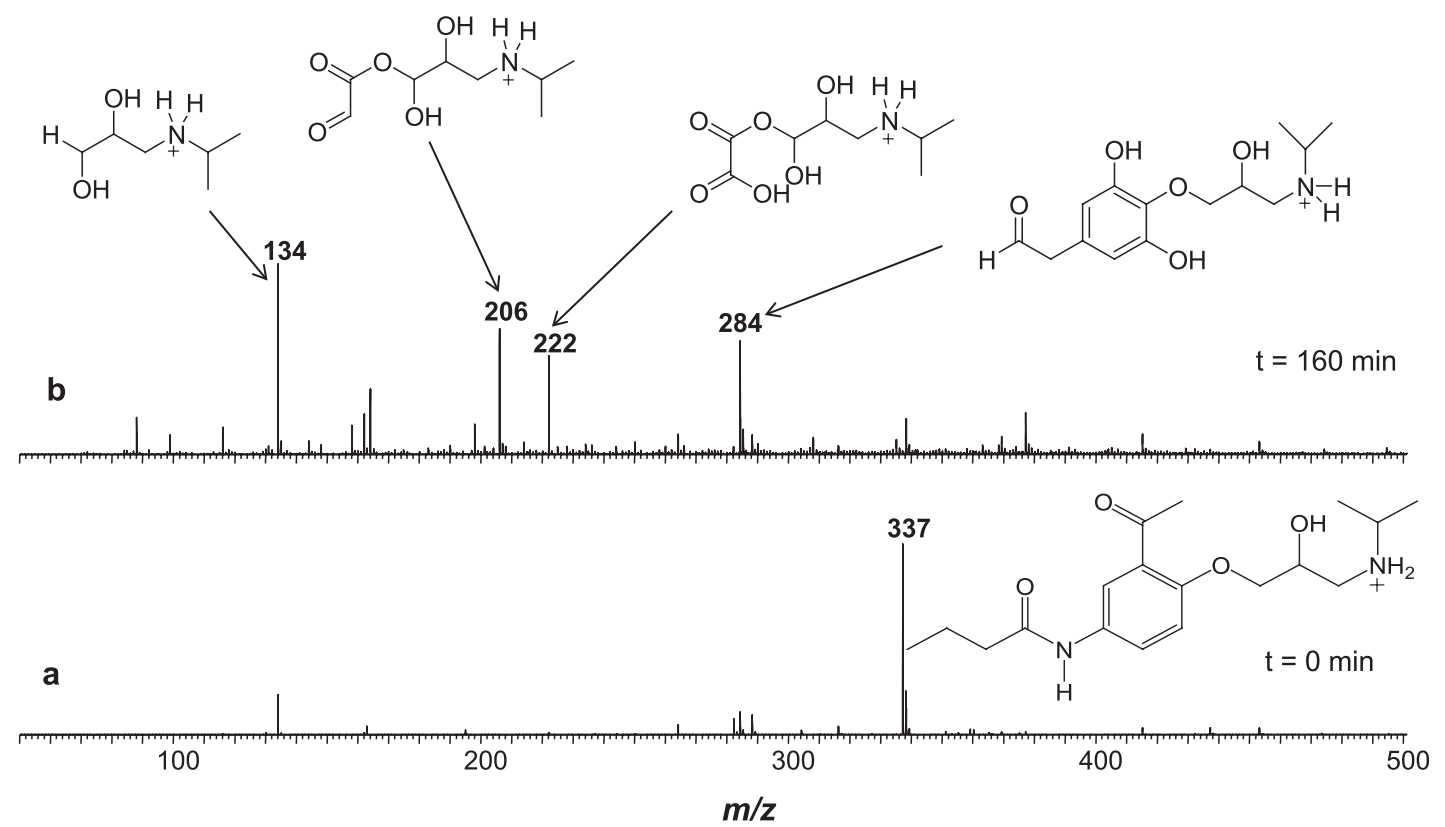

Figure 9. $\mathrm{ESI}(+)$ Mass spectra acquired for aliquots of the reaction mixture after $\mathrm{O}_{3}$ degradation of acebutolol for (a) 0 min and (b) $160 \mathrm{~min}$.

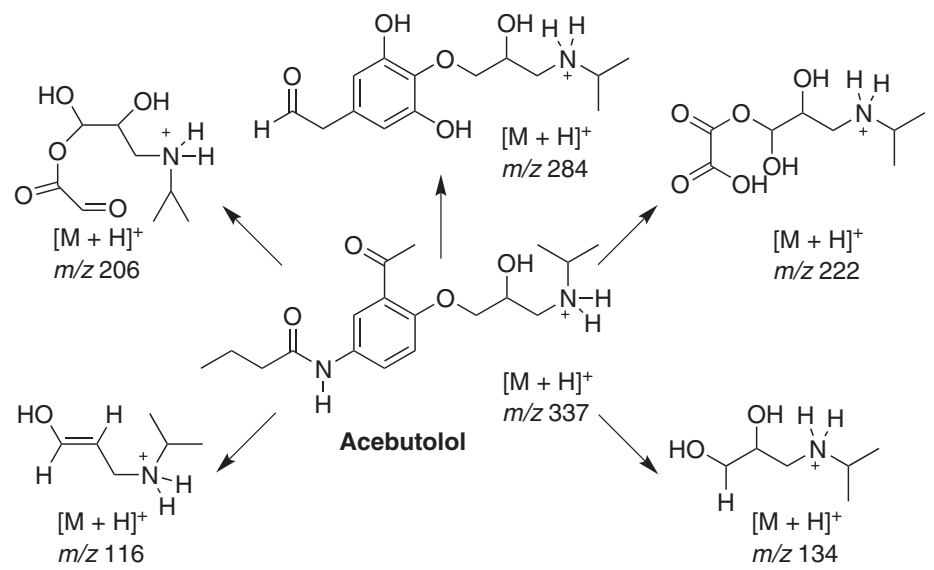

Figure 10. Mechanism proposed for acebutolol degradation by ozone based on ESI-MS(/MS) data.

After ozonation for 160 min (Figure 9b), acebutolol was completely consumed and four ions of $\mathrm{m} / \mathrm{z} 134,206,222$ and 284 were observed. These ions were characterized by ESI-MS/MS experiments and based on the MS data Figure 10 proposes a mechanism for its $\mathrm{O}_{3}$ treatment, assuming similar degradation pathways as proposed previously for atenolol and nadolol. Table 1 summarizes the accurate mass data of product ions for all species identified during the degradation processes of NAD, ATE and ACE.

\section{Conclusions}

As exemplified herein for three common pharmaceuticals, ESI mass spectrometry (and its tandem version) is a powerful technique able to provide detailed information about organic intermediates connecting parent molecules and final mineralization products during advanced oxidation processes. The ability to fish reactants, products, and intermediates (either ionic species or neutral species in their protonated or deprotonated forms) directly from the solution to the gas phase with gentleness, speed, and high sensitivity allows a detailed overview of the process and the interception and structural characterization of major players of the oxidation process. Whereas classical offline approaches such as GC-MS analysis can handle the more volatile and lighter species, the more polar, relatively unstable, or even transient intermediates or products, which may escape detection by other offline techniques or online techniques based on volatile species, may be intercepted and structurally characterized by online and real-time ESI-MS and ESI-MS/MS monitoring. 
Table 1. Accurate mass measurement of intermediate ions of nadolol (NAD), atenolol (ATE) and acebutolol (ACE) as determined by ESI-MS(/MS)

\begin{tabular}{|c|c|c|c|c|}
\hline \multirow{2}{*}{$\begin{array}{l}\text { Pharmaceutical } \\
\text { compounds }\end{array}$} & \multirow[t]{2}{*}{ Intermediate ion } & \multirow[t]{2}{*}{ Formula } & \multicolumn{2}{|c|}{ Mass $(m / z)$} \\
\hline & & & Experimental & Theoretical \\
\hline NAD & {$[1+\mathrm{H}]^{+}$} & $\mathrm{C}_{17} \mathrm{H}_{28} \mathrm{NO}_{4}$ & 310.2009 & 310.2018 \\
\hline (9) & {$\left[1+\mathrm{H}-\mathrm{C}_{6} \mathrm{H}_{6} \mathrm{O}_{2}+2 \mathrm{H}_{2} \mathrm{O}\right]^{+}$} & $\mathrm{C}_{11} \mathrm{H}_{26} \mathrm{NO}_{4}$ & 236.1843 & 236.1856 \\
\hline (7) & {$\left[1+\mathrm{H}-\mathrm{C}_{7} \mathrm{H}_{17} \mathrm{NO}_{2}+4 \mathrm{H}_{2} \mathrm{O}\right]^{+}$} & $\mathrm{C}_{10} \mathrm{H}_{18} \mathrm{O}_{6}$ & 235.1165 & 235.1176 \\
\hline (10) & {$\left[\mathbf{1}+\mathrm{H}-\mathrm{C}_{6} \mathrm{H}_{6} \mathrm{O}_{3}+2 \mathrm{H}_{2} \mathrm{O}\right]^{+}$} & $\mathrm{C}_{10} \mathrm{H}_{22} \mathrm{NO}_{4}$ & 220.1539 & 220.1543 \\
\hline (2) & {$\left[\mathbf{1}+\mathrm{H}-\mathrm{C}_{10} \mathrm{H}_{10} \mathrm{O}_{2}\right]^{+}$} & $\mathrm{C}_{7} \mathrm{H}_{18} \mathrm{NO}_{2}$ & 148.1319 & 148.1332 \\
\hline (3) & {$\left[2+\mathrm{H}-\mathrm{C}_{4} \mathrm{H}_{9}\right]^{+}$} & $\mathrm{C}_{3} \mathrm{H}_{9} \mathrm{NO}_{2}$ & 92.0691 & 91.0706 \\
\hline (4) & {$\left[2+\mathrm{H}-\mathrm{C}_{4} \mathrm{H}_{10}\right]^{+}$} & $\mathrm{C}_{3} \mathrm{H}_{8} \mathrm{NO}_{2}$ & 90.0556 & 90.0550 \\
\hline NAD & {$[\mathbf{1}-\mathrm{H}]^{-}$} & $\mathrm{C}_{17} \mathrm{H}_{26} \mathrm{NO}_{4}$ & 308.1873 & 308.1867 \\
\hline (11) & {$\left[1-\mathrm{H}-\mathrm{C}_{11} \mathrm{H}_{19} \mathrm{NO}_{2}+3 \mathrm{COO}\right]^{-}$} & $\mathrm{C}_{9} \mathrm{H}_{7} \mathrm{O}_{8}$ & 243.0129 & 243.0146 \\
\hline (8) & {$\left[\mathbf{5}-\mathrm{H}+2 \mathrm{OH}+2 \mathrm{H}_{2} \mathrm{O}\right]^{-}$} & $\mathrm{C}_{9} \mathrm{H}_{10} \mathrm{O}_{7}$ & 229.0347 & 229.0354 \\
\hline (5) & {$\left[\mathbf{1}-\mathrm{H}-\mathrm{C}_{11} \mathrm{H}_{19} \mathrm{NO}_{2}+\mathrm{O}_{3}\right]^{-}$} & $\mathrm{C}_{7} \mathrm{H}_{12} \mathrm{O}_{4}$ & 159.0677 & 159.0663 \\
\hline \multirow[t]{9}{*}{ ATE } & {$\left[\mathrm{M}+\mathrm{H}-\mathrm{NH}_{3}+2 \mathrm{OH}\right]^{+}$} & $\mathrm{C}_{14} \mathrm{H}_{22} \mathrm{NO}_{5}$ & 284.1482 & 284.1492 \\
\hline & {$[\mathrm{M}+\mathrm{H}]^{+}$} & $\mathrm{C}_{14} \mathrm{H}_{23} \mathrm{~N}_{2} \mathrm{O}_{3}$ & 267.1712 & 267.1703 \\
\hline & {$\left[\mathrm{M}+\mathrm{H}-\mathrm{C}_{2} \mathrm{H}_{6} \mathrm{NO}+\mathrm{OH}\right]^{+}$} & $\mathrm{C}_{12} \mathrm{H}_{18} \mathrm{NO}_{3}$ & 224.1275 & 224.1281 \\
\hline & {$\left[\mathrm{M}+\mathrm{H}-\mathrm{NH}_{3}-\mathrm{C}_{6} \mathrm{H}_{8} \mathrm{O}+4 \mathrm{OH}\right]^{+}$} & $\mathrm{C}_{8} \mathrm{H}_{16} \mathrm{NO}_{6}$ & 222.0961 & 222.0972 \\
\hline & {$\left[\mathrm{M}+\mathrm{H}-\mathrm{C}_{8} \mathrm{H}_{7} \mathrm{NO}+\mathrm{C}_{2} \mathrm{O}_{3}\right]^{+}$} & $\mathrm{C}_{8} \mathrm{H}_{16} \mathrm{NO}_{5}$ & 206.1018 & 206.1023 \\
\hline & {$\left[\mathrm{M}+\mathrm{H}-\mathrm{C}_{7} \mathrm{H}_{12} \mathrm{NO}+\mathrm{OH}\right]^{+}$} & $\mathrm{C}_{7} \mathrm{H}_{18} \mathrm{NO}_{3}$ & 164.1271 & 164.1281 \\
\hline & {$\left[\mathrm{M}+\mathrm{H}-\mathrm{C}_{8} \mathrm{H}_{17} \mathrm{NO}+2 \mathrm{OH}\right]^{+}$} & $\mathrm{C}_{6} \mathrm{H}_{8} \mathrm{NO}_{4}$ & 158.0443 & 158.0448 \\
\hline & {$\left[\mathrm{M}+\mathrm{H}-\mathrm{C}_{8} \mathrm{H}_{7} \mathrm{NO}\right]^{+}$} & $\mathrm{C}_{6} \mathrm{H}_{16} \mathrm{NO}_{2}$ & 134.1185 & 134.1176 \\
\hline & {$\left[\mathrm{M}+\mathrm{H}-\mathrm{C}_{8} \mathrm{H}_{9} \mathrm{NO}_{2}\right]^{+}$} & $\mathrm{C}_{6} \mathrm{H}_{14} \mathrm{NO}$ & 116.1077 & 116.1070 \\
\hline \multirow[t]{6}{*}{ ACE } & {$[\mathrm{M}+\mathrm{H}]^{+}$} & $\mathrm{C}_{18} \mathrm{H}_{29} \mathrm{~N}_{2} \mathrm{O}_{4}$ & 337.2127 & 337.2122 \\
\hline & {$\left[\mathrm{M}+\mathrm{H}-\mathrm{C}_{2} \mathrm{H}_{3} \mathrm{O}-\mathrm{C}_{4} \mathrm{H}_{8} \mathrm{ON}+2 \mathrm{OH}+\mathrm{C}_{2} \mathrm{H}_{2} \mathrm{O}\right]^{+}$} & $\mathrm{C}_{14} \mathrm{H}_{22} \mathrm{NO}_{5}$ & 284.1494 & 284.1492 \\
\hline & {$\left[\mathrm{M}+\mathrm{H}-\mathrm{C}_{12} \mathrm{H}_{14} \mathrm{NO}_{2}+\mathrm{C}_{2} \mathrm{HO}_{4}\right]^{+}$} & $\mathrm{C}_{8} \mathrm{H}_{16} \mathrm{NO}_{6}$ & 222.0972 & 222.0972 \\
\hline & {$\left[\mathrm{M}+\mathrm{H}-\mathrm{C}_{12} \mathrm{H}_{14} \mathrm{NO}_{2}+\mathrm{C}_{2} \mathrm{HO}_{3}\right]^{+}$} & $\mathrm{C}_{8} \mathrm{H}_{16} \mathrm{NO}_{5}$ & 206.1018 & 206.1023 \\
\hline & {$\left[\mathrm{M}+\mathrm{H}-\mathrm{C}_{12} \mathrm{H}_{13} \mathrm{NO}_{2}\right]^{+}$} & $\mathrm{C}_{6} \mathrm{H}_{16} \mathrm{NO}_{2}$ & 134.1174 & 134.1176 \\
\hline & {$\left[\mathrm{M}+\mathrm{H}-\mathrm{C}_{12} \mathrm{H}_{15} \mathrm{NO}_{3}\right]^{+}$} & $\mathrm{C}_{6} \mathrm{H}_{14} \mathrm{NO}$ & 116.1067 & 116.1070 \\
\hline
\end{tabular}

\section{Acknowledgments}

Financial support from the Proyecto Bicentenario de Ciencia y Tecnología PSD-16 and the Brazilian agencies FAPESP and CNPq is gratefully acknowledged. L. S. S. thanks FONDECYT (1085308) for financial support.

\section{References}

1. Daughton, C. G.; Ternes, T. A.; Environ. Health Perspect. 1999, 107, 907.

2. Ternes, T. A.; Water Res. 1998, 32, 3245.

3. Kolpin, D. W.; Skopec, M.; Meyer, M. T.; Furlong E. T.; Zaugg, S. D.; Sci. Total Environ. 2004, 328, 119.

4. Boyd, G. R.; Reemtsma, H.; Grimm, D. A.; Mitra, S.; Sci. Total Environ. 2003, 311, 135.
5. Glassmeyer, S. T.; Furlong, E. T.; Kolpin, D. W.; Cahill, J. D.; Zaugg, S. D.; Werner, S. L.; Meyer, M. T.; Kryak, D. D.; Environ. Sci. Technol. 2005, 39, 5157.

6. Halling-Sørensen, B.; Nors Nielsen, S.; Lanszky, P. F.; Ingerslev, F.; Holten Lützhaft, H. C.; Jørgensen, S. E.; Chemosphere 1998, 36, 357.

7. Halling-Sorensen, B.; Lykkeberg, A.; Ingerslev, F.; Blackwell, P; Tjornelund, J.; Chemosphere 2003, 50, 1331.

8. Snyder, S. A.; Westerhoff, P.; Yoon, Y.; Sedlak, D. L.; Environ. Eng. Sci. 2003, 20, 449.

9. Jones, O. A.; Lester, J. N.; Voulvoulis, N.; Trends Biotechnol. 2005, 23, 163.

10. Von Gunten, U.; Water Res. 2003, 37, 1443.

11. Staehelin S.; Hoigne J.; Environ. Sci. Technol. 1982, 16, 676.

12. Kasprzyk-Hordern, B.; Ziolek, M.; Nawrocki, J.; Appl. Catal., B 2003, 46, 639 . 
13. Quispe, C.; Villaseñor, J.; Pecchi G.; Reyes P.; J. Chil. Chem. Soc. 2006, 51, 1049.

14. Hernando, M. D.; Gomez M. J.; Aguera A.; Fernandez-Alba, A. R.; Trends Anal. Chem. 2007, 26, 581.

15. Eberlin, M. N.; Eur. J. Mass Spectrom. 2007, 13, 19.

16. Santos, L. S.; Knaack, L.; Metzger, J. O.; Int. J. Mass Spectrom. 2005, 246, 84.

17. Santos L. S.; Eur. J. Org. Chem. 2008, 235.

18. Dalmazio, I.; Santos, L. S.; Lopes, R. P.; Eberlin, M. N.; Augusti, R.; Environ. Sci. Technol. 2005, 39, 5982.

19. Domingos, J. B.; Longhinotti, E.; Brandao, T. A. S.; Bunton, C. A.; Santos, L. S.; Eberlin, M. N.; Nome, F.; J. Org. Chem. 2004, 69, 6024 .

20. Gozzo, F. C.; Santos, L. S.; Augusti, R.; Consorti, C. S.; Dupont, J.; Eberlin, M. N.; Chem. - Eur. J. 2004, 10, 6187.

21. Santos, L. S.; In Reactive Intermediates: MS Investigations in Solution; Santos, L. S., ed.; Wiley-VCH: Weinheim, 2010, ch. 5.
22. Chen, P.; Angew. Chem., Int. Ed. 2003, 42, 2832.

23. Vogna, D.; Marotta, R.; Andreozzi, R.; Napolitano, A.; d'Ischia, M.; Chemosphere 2004, 54, 497.

24. Moura, F. C. C.; Araujo, M. H.; Dalmazio, I.; Alves, T. M. A.; Santos, L. S.; Eberlin, M. N.; Augusti, R.; Lago, R. M.; Rapid Commun. Mass Spectrom. 2006, 20, 1859.

25. Yang, H.; An, T.; Li, G.; Song, W.; Cooper, W. J.; Luo, H.; Guo, X.; J. Hazard. Mat. 2009, 179, 834.

26. Marco-Urrea, E.; Radjenovic, J.; Caminal, G.; Petrovic, M.; Vicent, T.; Barcelo, D.; Water Res. 2010, 44, 521.

Submitted: June 3, 2010

Published online: February 3, 2011

FAPESP has sponsored the publication of this article. 